\title{
MANAJEMEN PENDIDIKAN KARAKTER GOTONG ROYONG
}

\author{
Irwan Maulana
}

UIN Sunan Gunung Djati Bandung

Email: maulanairwan392@gmail.com

\begin{abstract}
ABSTRAK
Manajemen Pendidikan Karakter Gotong Royong di Pesantren Ummul Quro alIslami Leuwiliang Bogor tidak terlepas dari fungsi-fungsi Manajemen Pendidikan Karakter. Fungsi Manajemen Pendidikan Karakter mencakup perencanaan, pengorganisasian, pelaksanaan, dan pengawasan. Metode Penelitian ini adalah metode deskriptif dengan pendekatan kualitatif. Teknik pengumpulan data yang digunakan yaitu observasi, wawancara, dan studi dokumentasi. Karakter Gotong Royong tidak dirumuskan dalam Perencanaan Manajemen Pendidikan Karakter Gotong Royong, akan tetapi, dalam Pelaksanaannya Karakter Gotong Royong nampak pada komponen pesantren. Standar Operational Procedure disampaikan secara lisan dan tidak ditulis untuk Majelis Pembimbing Organisasi, akan tetapi, dalam pelaksanaannya dilaksanakan dengan baik yang meliputi membimbing, mendidik, mengarahkan, dan mengayomi. Pengawasan Manajemen Pendidikan Karakter Gotong Royong menggunakan metode langsung, semi langsung dan tidak langsung. Evaluasi yang digunakan terbagi menjadi dua, evaluasi wajib dan berdasarkan kesepakatan. Evaluasi wajib dilaksanakan dua minggu sekali sedangkan evaluasi berdasarkan kesepakatan dilaksanakan satu minggu sekali.
\end{abstract}

Kata kunci: Manajemen, Karakter, Organisasi

\section{ABSTRACT}

Management of Mutual Cooperation Character Education in the Islamic Boarding School of Quro al-Islami Leuwiliang Bogor is inseparable from the functions of Character Education Management. The Character Education Management function includes planning, organizing, implementing, and monitoring. This research method is a descriptive method with a qualitative approach. Data collection techniques used were observation, interviews, and documentation studies. The character of Mutual Cooperation is not formulated in the Mutual Cooperation Character Education Management Planning, however, in the Implementation of the Mutual Cooperation Character it appears in the components of the pesantren. The Operational Procedure standard is delivered verbally and is not written for the Organizational Supervisory Board, however, in its implementation it is carried out well which includes guiding, educating, directing, and protecting. Management of Mutual Cooperation Character 
Education Management uses direct, semi-direct and indirect methods. The evaluation used is divided into two, mandatory evaluations and based on agreement. Evaluation must be carried out every two weeks while agreement based on agreements is conducted once a week.

Key Word: Management, Character, Organization

\section{PENDAHULUAN}

Pendidikan adalah alat penting dalam pembangunan masyarakat. Meskipun hasil pembangunan melalui pendidikan lambat, namun sangat pasti dalam pembangunan masyarakat. Pendidikan adalah suatu proses dengan menggunakan metode-metode tertentu sehingga orang mendapatkan pengetahuan, pemahaman, dan cara bertindak yang sesuai dengan kebutuhan (Muhibbin Syah et al., 2017, hlm. 10). Salah satu output yang terpenting dari proses pendidikan adalah akhlak al-karimah atau karakter sebagaimana tertera dalam Tujuan Pendidikan Nasional Undang-undang nomor 13 tahun 2003. Karakter yang dimaksud tentu perlu dirumuskan supaya dapat dituangkan ke dalam RPP.

Lima nilai utama PPK (Penguatan Pendidikan Karakter) memiliki peran yang sangat penting dalam memajukan karakter bangsa, karakter tersebut adalah; 1) Religius; 2) Integritas; 3) Mandiri; 4) Nasionalis; 5) Gotong Royong. Kelima karakter teresbut perlu diajarkan di dalam Lembaga pendidikan melalui moral knowing, moral understanding, dan moral doing. Salah satu permasalahan bangsa yang sekarang dialami alami adalah lunturnya budaya saling sapa, saling peduli satu sama lain, pudarnya budaya menghargai kinerja satu sama lain, dan saling membantu. Karakter Gotong Royong nampaknya menjadi salah satu solusi dalam mengentaskan permasalahan tersebut.

Gotong Royong merupakan kerja sama antara anggota-anggota suatu komunitas (Koentjaraningrat, 2009, hlm. 2). Definisi yang lain mengatakan gotong royong adalah suatu kegiatan yang dilaksanakan secara bersama-sama yang dianggap berguna bagi individu lainnya (Marzali, 2009, hlm. 149). Oleh karena itu, gotong royong merupakan suatu kegiatan yang dilakukan secara bersama-sama oleh individu atau kelompok dengan cara terlibat aktif di dalamnya.

Untuk menanamkan karakter gotong royong diperlukan Manajemen Pendidikan Karakter. Manajemen Pendidikan Karakter setidaknya memainkan fungsinya sebagai berikut: 1) Perencanaan; 2) Pelaksanaan; 3) Pengawasan (Mulyasa, 2014, hlm. 64). Hal ini penting karena pada tahap perencanaan tidak lepas dari pertanyaan-pertanyaan program apa yang dibuat? Kenapa dilaksanakan? Siapa yang melaksanakan? Kapan dilaksanakan? Dimana dilaksanakan? Dan bagaimana melaksanakannya? Sedangkan pada tahap pelaksanaan harus dilakukan dengan cara mengacu terhadap perencanaan. Pengawasan dilaksanakan dengan metode yang dianggap paling efektif dan efisien oleh Lembaga Pendidikan tersebut.

Dalam rangka melaksanakan manajemen pendidikan karakter gotong royong maka diperlukan wadah guna melaksanakannya. Wadah tersebut disebut organisasi. Di dalam organisasi terdapat sekumpulan orang-orang, tujuan, 
aturan, dan sistem sehingga Peserta Didik dapat merasakan dinamika secara langsung yang ada di dalamnya.

Dalam hal ini, Pesantren Ummul Quro al-Islami menjadi Lembaga Pendidikan yang menarik untuk diteliti terutama dari Manajemen Pendidikan Karakter Gotong Royong dengan segala keunikannya misalnya Pelaksana Manajemen Pendidikan Karakter Gotong Royong dilaksanakan Majelis Pembimbing Organisasi (MPO) dan Pengurus Ikatan Santri Putera (ISPA). MPO menggunakan Metode Central dan Branch yang membedakan dengan pesantren yang lainnya (Hasil Studi Dokumentasi 4 Mei 2019 ceramah Pimpinan Pesantren Ummul Quro al-Islami K.H. Abdul Mubin LC).

Selain itu, tidak ada perumusan karakter gotong royong secara spesifik yang dilakukan oleh MPO dan pengurus ISPA akan tetapi, karakter gotong royong tersebut nampak dalam kehidupan sehari-hari baik dilakukan oleh kalangan santri, atau kalangan asatidz (Guru-guru). Selain itu, tidak ada Standar Operational Procedure (SOP) yang tertulis pada MPO akan tetap pelaksanaannya dilaksanakan dengan baik misalnya dengan adanya komunikasi yang baik, saling bahu membahu dalam memecahkan masalah, rasa peduli, dan saling empati.(Wawancara dengan Ustadz Syamsul Rizal, Ustadz Syafi'l ketua dan Sekretaris MPO serta observasi lapangan 1-8 April 2019).

Sistem EDP (Electronic Data Process) menjadi salah satu keunikan tersendiri dalam menjalankan fungsi Manajemen Pendidikan Karakter Gotong Royong di Pesantren Ummul Quro al-Islami. Santri yang melanggar disiplin pesantren akan dikurangi pointnya serta akan menjadi salah satu pertimbangan kenaikan kelasnya serta menjadi laporan kepada wali santri yang ditulis melalui rapot suluk (Rapot akhlak). (Wawancara dengan Ustadz Bahrul Ulum, Ketua Bagian Ta'lim dan Tarbiyatul adab 5 April 2019).

Berdasarkan penelitian keunikan di atas, maka penelitian ini ditujukan untuk memberikan penekanan baru bagi penelitian terdahulu yang belum maksimal, terutama dalam Manajemen Pendidikan Karakter di Pesantren Ummul Quro al-Islami Leuwiliang Bogor yang tidak adanya SOP bagi MPO akan tetapi pada pelaksanaannya berjalan dengan baik. Oleh karena itu, hal ini yang melatar belakangi peneliti mengkaji Manajemen Pendidikan Karakter Gotong Royong di Pesantren Ummul Quro al-Islami Leuwiliang Bogor.

Manajemen Pendidikan pada dasarnya adalah manajemen yang diterapkan dalam pengembangan pendidikan (Muhaimin, 2010, hlm. 5). Manajemen Pedidikan diterapkan untuk mempermudah Lembaga pendidikan meraih tujuan pendidikan salah satunya adalah karakter. Untuk meraih karakter yang baik maka diperlukan Manajemen Pendidikan Karkter. Manajemen Pendidikan Karakter berperan dalam pembentukan karakter peserta didik. Manajemen Pendidikan Karakter tidak lepas daripada fungsi manajemen yang meliputi perencanaan, pelaksanaan, dan pengawasan (Mulyasa, 2012, hlm. 64). Pada tahap perencanaan, ada beberapa tahap yang perlu diperhatikan seperti mengidentifikasi karakter, mengintegrasikan karakter ke dalam Kompetensi Dasar, dan menyusun RPP (Mulyasa, 2011, hlm. 79). Karakter yang perlu dirumuskan adalah karakter yang tertera dalam lima Penguatan Pendidikan Karakter yaitu 1) Religius; 2) Integritas; 3) Mandiri; 4) Nasionalis; 5) Gotong Royong. Karakter Gotong Royong menjadi salah satu karakter penting yang perlu dirumuskan dalam membentuk peserta didik yang saling peduli satu sama lain. 
Selain itu, pada tahap perencanaan harus dapat menjawab pertanyaan $5 \mathrm{~W}+1 \mathrm{H}$ (Badrudin, 2013, hlm. 15)

Penerapan Manajemen Pendidikan Karakter pada Peserta Didik diperlukan tempat agar Peserta Didik mampu merasakan secara langsung dinamika yang ada. Tempat yang dibutuhkan adalah organisasi.Organisasi secara etimologi berasal dari kata organon dalam Bahasa Yunani yang berarti alat (Asmani, 2012, hlm. 17). Sedangkan pengertian yang lain terkait organisasi adalah bentuk Lembaga yang dominan dalam masyarakat (Robbins, 1996, hlm. 9). Oleh karena itu, dapat disimpulkan bahwa organisasi adalah sebuah wadah yang digunakan untuk meraih tujuan bersama.

Di dalam organisasi diperlukan unsur-unsur organisasi. Unsur-unsur organisasi (Aziz, 2011, hlm. 4) adalah:

1. Terdapat orang-orang sebagai sebuah entitas sosial;

2. Bertujuan atau diarahkan oleh tujuan;

3. Memiliki sistem kegiatan terstruktur yang disengaja;

4. Adanya batas-batas yang jelas.

Pesantren merupakan Lembaga pendidikan yang memiliki sistem pendidikan dua puluh empat jam. Di dalam Undang-undang Sistem Pendidikan Nasional No. 20 Tahun 2003 pasal 30 ayat 4 menyebutkan bahwa, "Pendidikan keagamaan berbentuk pendidikan dinniyah, pesantren, persamaan, pabhaja, samanera, dan bentuk lainnya yang sejenis". Dalam definisinya, pesantren didefinisikan di dalam Peraturan Pemerintah No. 55 tahun 2007 tentang pendidikan agama dan keagamaan, dalam pasal 1 ayat 4 dijelaskan bahwa, "pesantren atau pondok pesantren adalah Lembaga pendidikan keagamaan Islam berbasis masyarakat yang menyelenggarakan pendidikan diniyyah atau secara terpadu dengan pendidikan jenis lainnya".

Pesantren memiliki tujuan tersendiri dalam memajukan bangsa. Tujuan Pesantren terdiri dari tujuan umum dan tujuan khusus. Tujuan umum Pesantren adalah membimbing anak didik untuk menjadi manusia yang berkepribadian Islam. Sedangkan tujuan khususnya adalah mempersiapkan para santri untuk menjadi orang alim dalam ilmu agama yang dianjurkan Kiyai yang bersangkutan dan mengamalkannya dalam masyarakat (Mahmud, 2012, hlm. 193).

Komponen-komponen pesantren adalah sebagai berikut:

1. Pondok;

2. Masjid;

3. Pengajaran kitab kuning;

4. Kiyai;

5. Santri (Dhofier, 2015, hlm. 83-99)

Dalam perkembangannya, pesantren mengalami perkembangan sehingga melahirkan tipe-tipe pesantren dalam perkembangannya, yaitu:

1. Pesantren Salafi;

2. Pesantren Semi berkembang;

3. Pesantren berkembang;

4. Pesantren modern;

5. Pesantren ideal.

Perkembangan pesantren di atas memiliki fungsi yang berbeda tergantung dari jenis pesantren yang berkembang karena pada dasarnya 
pesantren tersebut berkembang karena sebagai salah satu respon dalam perkembangan zaman.

\section{METODE}

Pendekatan yang digunakan dalam penelitian ini adalah pendekatan kualitatif. Pendekatan Kulalitatif adalah metode penelitian yang berlandaskan positivism (Sugiyono, 2013, hlm. 9). Pendekatan ini dilakukan untuk mendapatkan data tentang kondisi sebenarnya di lokasi penelitian. Teknik pengumpulan data menggunakan Teknik wawancara, observasi partisipasi, dan studi dokumentasi. Teknik Wawancara dilakukan dengan cara tanya jawab dengan narasumber. Teknik observasi partisipasi dilakukan dengan cara peneliti terjun langsung ke lapangan dengan cara mengamati dengan menggunakan seluruh panca indera, sedangkan Teknik Studi Dokumentasi dilakukan dengan tujuan memperoleh data-data yang dibutuhkan melalui dokumen, gambar, fotofoto, dan video yang berkaitan dengan objek penelitian. Analisis Data Penelitian menggunakan unitisasi data, kategorisasi data, dan penafsiran data. Sedangkan Uji Keabsahan Data Penelitian dilakukan dengan cara Perpanjangan pengamatan, peningkatan ketekunan dan triangulasi data. Dalam triangulasi terdapat beberapa pendekatan yang digunakan, yaitu triangulasi metode. Triangulasi metode dilakukan dengan cara membandingkan satu metode dengan metode lain. Triangulasi antar-peneliti dilakukan dengan menggunakan banyak key-informant. Triangulasi Sumber data dengan cara menggunakan berbagai sumber data. Triangulasi Teori digunakan dengan cara membandingkan satu teori dengan teori yang lain yang lebih relevan. Analisa Kasus Negatif menggunakan bahan referensi, member check, dan dan keikutsertaan. Proses ini dilakukan dengan tujuan memperoleh data yang sebenarnya di lapangan.

\section{HASIL DAN PEMBAHASAN \\ Realitas Objektif Pesantren Ummul Quro al-Islami}

Pesantren Ummul Quro al-Islami Leuwiliang Bogor didirikan oleh K.H Helmy Abdul Mubin, LC pada 21 Juli 1993 bertepatan dengan 1 Muharram 1413 $\mathrm{H}$. Peletakan batu pertama dilakukan oleh Rois 'Am NU cabang Bogor $\mathrm{KH}$. Mukhtar Royani dan bapak MUSPIKA (Bapak Camat, DANRAMIL dan Kapolsek). Nama Pesantren Ummul Quro al-Islami diambil dari salah satu julukan kota suci Mekah yang berarti ibu desa-desa sebagai bentuk tabbarukan dengan kota tersebut. Jika kota Mekah dibanjiri kaum muslimin dari berbagai negara, maka Pesantren Ummul Quro berharap akan dibanjiri oleh santri-santri yang berasal dari berbagai daerah di Indonesia dan tidak menutup kemungkinan dari berbagai negara. Lokasi Pesantren Ummul Quro al-Islami berada di kampung Banyusuci desa Leuwimekar Bogor, berdekatan dengan perumahan warga sekitar. Di sampig Pesantren berdekatan dengan sungai Cianten. Alamat lengkap Pesantren Ummul Quro al-Islami berada di Jl. Moh Noh Noer Rt.004/004 Kp. Banyusuci, Desa, Leuwimekar, Leuwiliang, Bogor, Jawa Barat 16640.

Pesantren Ummul Quro al-Islami memiliki Visi yaitu Menjadi Generasi yang unggul dalam prestasi, berakhlak karimah, tekun beribadah berdasarkan paham ahlusunnah wal jamaah. Sumber Daya Manusia yang dimiliki Pesantren ini terdiri dari berbagai latar belakang, yaitu lulusan Pesantren Ummul Quro al- 
Islami yang diminta atau mengajukan diri untuk mengabdi di Pesantren, lulusan perguruan tinggi, dan lulusan pesantren salafi.

Sumber Daya Pesantren Ummul Quro al-Islami berjumlah 216 orang dengan rincian 128 orang laki-laki, dan 28 orang perempuan. Pesantren Ummul Quro al-Islami memiliki dua struktur organisasi, yaitu struktur organisasi Yayasan pesantren, dan struktur organisasi pesantren. Dalam Manajemen Santri, pesantren Ummul Quro al-Islami memiliki organisasi tersendiri yaitu Majelis Pembimbing Organisasi. Anggota yang menjabat sebagai Majelis Pembimbing Organisasi berjumlah 49 orang dengan menduduki berbagai bagian. Dalam rangka mewujudkan pengelolaan santri yang baik, maka Majelis Pembimbing Organisasi memiliki bagian-bagian khusus dalam mewujudkan pengeolaan santri yang baik.

\section{Perencanaan Manajemen Pendidikan Karakter Gotong Royong}

Perencanaan menurut Sudjana (2004) yang dikutip dari Jurnal Administrasi dan Manajemen Pendidikan (Maisaro et al., 2018, hlm. 304) berkaitan dengan rangkaian kegiatan yang akan dilaksanakan guna mencapai tujuan di masa yang akan datang. Perumusan perencanaan merupakan penetapan jawaban kepada enam pertanyaan, yaitu: 1) Tindakan apa yang harus dikerjakan?; 2) Apakah sebabnya tindakan tersebut harus dikerjakan?; 3) Dimana tindakan tersebut dilaksanakan?;4) Siapa yang akan mengerjakan tindakan tersebut?; 5) Bagaimana cara melaksanakan tindakan tersebut? (Badrudin, 2013, hlm. 15). Dalam Perencanaan Manajemen Pendidikan Karakter, maka harus ada identifikasi karakter, integrase karakter ke dalam kompetensi dasar, dan penyusunan RPP berkarakter (Mulyasa, 2011, hlm. 79). Dalam hal ini, maka Karakter Gotong Royong perlu dirumuskan sebagai salah satu karakter penting untuk ditanamkan ke dalam jiwa peserta didik. Dalam hal ini, maka Karakter Gotong Royong perlu dipaparkan apa saja yang menjadi indikator karakter gotong royong. Indikator Karakter Gotong Royong yang dirujuk dalam penelitian ini berdasarkan indikator Karakter Gotong Royong yang dijelaskan oleh KEMINDIKBUD yang dikutip dari www.kemendikbud.com yaitu:

1. Mencerminkan tindakan menghargai semangat kerja sama dan bahu membahu menyelesaikan persoalan bersama;

2. Menjalin komunikasi dan persahabatan;

3. Memberi bantuan/pertolongan pada orang-orang yang membutuhkan;

4. Siswa dapat menunjukkan sikap menghargai sesama, dapat bekerja sama, inklusif, mampu berkomitmen atas keputusan bersama, musyawarah mufakat, tolong menolong;

5. Memiliki empati dan rasa solidaritas, anti diskriminasi, anti kekerasan, dan sikap kerelawanan.

Tujuan Manajemen Pendidikan Karakter Gotong Royong juga harus sesuai dengan Tujuan Pendidikan Nasional yaitu sebagai rumusan kualitas yang harus dimiliki setiap warga negara Indonesia, dikembangkan oleh berbagai satuan pendidikan di berbgai jenjang dan jalur. Tujuan pendidikan nasional memuat berbagai nilai kemanusian yang harus dimiliki warga negara indonesia. Oleh karena itu, tujuan pendidikan nasional adalah sumber yang paling oprasional dalam pengembangan pendidikan budaya karakter bangsa (Rica, 2017, hlm. 36). Perencanaan Manajemen Pendidikan Karakter Gotong Royong 
santri dilakukan dengan cara merumuskan tujuan yang ingin dicapai. Perumusan Karakter Gotong Royong tidak dirumuskan karena pesantren mengajarkan ilmu kehidupan yang didalamnya tidak lepas dari interaksi dan karakter gotong royong. Selanjutnya adalah merumuskan program sebagai wadah pembentukan Karakter Gotong Royong. Dalam rangka peningkatan Karakter maka pesantren merumuskan tiga program, yaitu (1) Tarbiyatul Adab (2) Kuliah ashar (3) Tandziful 'am (bersih-bersih).

Meskipun Karakter Gotong Royong tidak dirumuskan secara tertulis, akan tetapi secara implisit ketiga program tersebut mengandung karakter gotong royong. Karakter Gotong Royong yang ada dalam Tarbiyatul Adab adalah saling menghargai satu sama lain, tidak boleh menghina satu sama lain, saling tolong menolong satu sama lain. Pada program kuliah asar yang dilaksanakan dengan pimpinan pesantren satu minggu satu kali mengandung karakter gotong royong adalah kesadaran empati satu sama lain. Dalam program tandzhiful 'am dilaksanakan satu minggu satu kali dari pukul 07.00-09.00 wib di bawah bagian kebersihan. Karakter Gotong Royong yang terkandung adalah kesadaran dalam bekerja bersama-sama, saling bahu membahu, saling menghargai satu sama lain. Pada dasarnya Perencanaan Manajemen Pendidikan Karakter Gotong Royong di Pesantren Ummul Quro al-Islami sudah sesuai dilaksanakan sebagaimana teori yang sudah dijelaskan di atas, akan tetapi, pada tahap perumusan karakter gotong royong perlu di rumuskan secara detail.

\section{Pengorganisasian Manajemen Pendidikan Karakter Gotong Royong}

Pengorganisasian merupakan fungsi Manajemen Pendidikan yang sangat penting dalam menentukan keberhasilan Lembaga pendidikan. Fungsi Pengorganisasian Manajemen Pendidikan adalah fungsi yang berhubungan sangat erat dengan perencanaan (Rivai, 2009, hlm. 103). Dalam hal ini, maka pengorganisasian sangat erat kaitanya dengan pembagian kerja, pengelompokan kerja, dan penentuan relasi antar bagian (Badrudin, 2013, hlm. 115).

Pengorganisasian merupakan proses penyusunan struktur organisasi yang sesuai dengan tujuan organisasi, sumber-sumber daya yang dimilikinya, dan lingkungan yang dimilikinya. Supaya dapat dipahami dengan baik mengenai pengorganisasian, maka perlu diketahui tentang ruang lingkup pengorganisasian. Ruang lingkup pengorganisasian yaitu:

1. Mengelompokan orang-orang;

2. Penetapan tugas;

3. Penetapan fungsi;

4. Wewenang;

5. Tanggung jawab. (Badrudin, 2013, hlm. 16)

Pengorganisasian Manajemen Pendidikan Karakter Ummul Quro al-Islami dilaksanakan dengan beberapa tahap. Pada tataran Majelis Pembimbing Organisasi menggunakan Teknik musyawarah dan seleksi. Ada pun tahapanya adalah staffing yang dilakukan dengan cara membagikan angket kepada calon pengurus Majelis Pembimbing Organisasi untuk memilih bagian yang mereka minati. Fungsi staffing adalah kegiatan untuk memperoleh orang yang efektif akan mengisi jabatan-jabatan kosong di organisasi (Badrudin, 2013: 138). Setelah calon pembimbing memlilih bagian yang mereka minati, maka angket 
tersebut dikumpulkan dan akan dimusyawarahkan dengan melihat track record calon pengurus Majelis Pembimbing Organisasi serta kemampuan yang dibutuhkan. Malayu Hasibuan mendefinsikikan seleksi sebagai suatu kegiatan pemilihan dan penentuan pelamar yang diterima atau ditolak untuk ditempatkan di organisasi (Badrudin, 2013, hlm. 141). Setelah itu, maka akan dilakukan departemenisasi dengan cara mengelompokan pengurus Majelis Pembimbing Organisasi yang ahli dalam bidang-bidangnya masing-masing. tahap selanjutnya adalah membuat bagan dan alur koordinasi. Hal ini bertujuan memberikan arahan yang jelas tentang jalur komunikasi dan koordinasi.

Dalam Pengurus Ikatan Santri Putera (ISPA), pengorganisasian Manajemen Pendidikan Karakter Gotong Royong dilaksanakan dengan Teknik musyawarah dan seleksi. Pada tahap awal pengorganisasian dibentuk Karantina khusus untuk calon ketua ISPA dalam rangka memberikan pemahaman lebih dalam mengenai kepemimpinan, kebidangan, dan kepesantrenan. Tahap selanjutnya yaitu Latihan Dasar Kepemimpinan yang iperuntukan seluruh calon pengurus ISPA. setelah itu, tahap selanjutnya adalah di adakanya pemilu santri. Pemilu santri diadakan dalam rangka memilih calon ketua ISPA. setelah ketua ISPA terpilih maka dilaksanakan tahap staffing. Tahap ini dilakukan dengan menggunakan pendekatan msuyawarah dan seleksi. Calon pengurus ISPA diberikan angket untuk memilih bagian yang mereka minati yang nantinya akan dipertimbangkan bersama ketua ISPA dan akan disahkan oleh Ketua Majelis Pembimbing Organisasi serta Sekretaris Majelis Pembimbing Organisasi.

Tahap selanjutnya adalah dilaksanakan departemenisasi dengan cara menempatkan orang-orang yang ahli pada bidangnya masing-masing. setelah itu, setelah itu, dibentuklah Bagan Koordinasi supaya membuat jelas alur komunikasi dan koordinasi.

\section{Pelaksanaan Manajemen Pendidikan Karakter Gotong Royong}

Pelaksanaan adalah fungsi manajemen yang terpenting dan paling dominan dalam proses manajemen (Rivai, 2009, hlm. 103). Proses pelaksanaan pendidikan karakter di sekolah meliputi, kurikulum, pendidik, peserta didik, alat pendidikan, strategi dan metode (Rusmaini, 2017, hlm. 144). Pelaksanaan Manajemen Pendidikan Karakter dilaksanakan dengan adanya sinergi antara pengurus Majelis Pembimbing Organisasi dan pengurus Ikatan Santri Putera. Program Kerja di Pesantren Ummul Quro al-Islami terdapat empat program, yaitu program harian, program mingguan, program bulanan, program tahunan dan incidental. Program-program ini dilaksanakan oleh masing-masing bidang yang mempunyai program kerja tersebut. Dalam Pelaksanannya, Majelis Pembimbing Organisasi menjalankan fungsinya, yaitu:

\section{Mendidik}

Mendidik yang dilakukan oleh Majelis Pembimbing Organisasi adalah dengan cara penugasan. Santri diberikan tugas melalui Pengurus Ikatan Santri Putera dengan learning by knowing, learning by thinking, learning by doing. Learning by knowing dilaksanakan dengan cara memberikan pengetahuan mana yang baik, dan mana yang buruk, leaning by thinking dilaksanakan dengan cara santri dibiarkan untuk memikirkan akibat dari tindakan tersebut. sedangkan learning by doing santri dapat mempraktikan pengetahuannya tersebut kedalam kehidupanya sehari hari. 
2. Mengarahkan

Mengarahkan yang dilakukan oleh Majelis Pembimbing Organisasi adalah dengan cara memberikan pemahaman serta menunjukan apa yang harus dilakukan seharusnya.

3. Mendampingi

Dalam melaksanakan salah satu tugasnya, proses mendampingi dilaksanakan oleh Majelis Pembimbing Organisasi dengan cara menemani dan mengarahkan baik di dalam program kerja atau pun di luar program kerja.

4. Mengayomi

Majelis Pembimbing Organisasi melakukan pengayoman kepada santri dengan cara memberikan bantuan moral seperti nasihat dan tindakan nyata.

5. Mendorong

Mendorong sama saja dengan memotivasi. Dalam menjalankan salah satu fungsinya, Majelis Pembimbing Organisasi melaksanakan tugas ini dengan cara memberikan motivasi kepada santri baik dalam rangka menumbuhkan motivasi internal atau pun eksternal.

Program yang dirumuskan dalam rangka meningkatkan Karakter dilaksanakan dengan baik. Ada pun Karakter yang nampak dalam program yang dibentuk untuk meningkatkan karakter gotong royong adalah sebagai berikut:

1. Tarbiyatul adab

Karakter Gotong yang nampak di lapangan Seperti santri lebih peka dalam melaksanakan hubungan baik kepada sesama manusia seperti saling membantu, saling peduli, saling menghormati, dan saling menjaga prilaku satu sama lain karena anjuran dalam agama Islam.

2. Kuliah Asar

Karakter Gotong Royong yang nampak di lapangan melalui program ini seperti menghargai teman sesama, bekerjasama dalam beramal baik sebagai bentuk ibadah kepada Allah, peduli terhadap sesama manusia karena akan melahirkan persaudaraan, menjaga komunikasi yang baik dan pada tempatnya.

3. Tandziful 'am

Karakter Gotong Royong yang nampak melalui program ini seperti karakter saling peduli, tanggung jawab, dan mempercayai satu sama lain.

Karakter Gotong Royong nampak pada program dan di luar program baik pada Majelis Pembimbing Organisasi, pengurus Ikatan Santri Putera, dan seluruh komponen Pesantren Ummul Quro al-Islami. Ada pun karakter gotong royong yang nampak adalah sebagai berikut:

a. Mencerminkan tindakan menghargai semangat kerja sama dan bahu membahu menyelesaikan persoalan bersama;

b. Menjalin komunikasi dan persahabatan;

c. Memberi bantuan/ pertolongan kepada orang-orang yang membutuhkan;

d. Dapat menunjukkan sikap menghargai sesama, dapat bekerja sama, inklusif, mampu berkomitmen atas keputusan bersama, musyawarah mufakat, tolong menolong;

e. Memiliki empati dan rasa solidaritas, anti diskriminasi, anti kekerasan, dan sikap kerelawanan

\section{Pengawasan Manajemen Pendidikan Karakter Gotong Royong}


Pengendalian atau pengawasan adalah fungsi terakhir dari manajemen (Badrudin, 2013: 215). Fungsi pengawasan ini sangat penting dan sangat menentukan pelaksanaan proses manajemen, peranan pengawasan juga sangat menentukan baik atau buruknya suatu rencana, oleh karena itu harus dilakukan dengan sebaik-baiknya (Maisaro et al., 2018, hlm. 302-312). Kegiatan ini untuk meneliti dan memerikasa apakah pelaksanaan tugas-tugas perencanaan betulbetul dikerjakan atau tidak (Samsirin, 2015, hlm. 324) sebagai fungsi sistem yang melakukan penyesuaian terhadap rencana, mengusahakan agar penyimpanganpenyimpangan hanya dalam batas-batas yang dapat ditoleransi. Pengawasan memiliki jenisnya masing-masing. jenis-jenis ini yang akan menentukan keberhasilan sebuah organisasi dalam pengawasan.

Pengendalian memiliki beberapa jenis, yaitu pengendalian secara langsung, dan pengendalian secara tidak langsung. Pengendalian secara langsung yaitu pengendalian yang dilakukan sendiri oleh seorang manajer. Sedangkan pengendalian secara tidak langsung dilakukan dengan cara dengan cara memberikan laporan kepada seorang manajer. Pengawasan dalam Manajemen Pendidikan Karakter Gotong Royong di Pesantren Ummul Quro alIslami dilaksanakan dengan menggunakan metode langsung, semi langsung, dan tidak langsung. Metode ini dilakukan dengan karena dianggap efektif oleh Pesantren Ummul Quro al-Islami. Ada pun penjelasannya sebagai berikut:

1. Metode Langsung

Metode langsung adalah metode seorang pengawas terjun langsung ke lapangan. Dalam kaitannya dengan ini, maka metode pengawasan langsung diterapkan dengan cara Pengurus Majelis Pembimbing Organisasi terlibat di dalam sebuah program tersebut. Dalam kaitannya dengan pengurus Ikatan Santri Putera maka ketua Ikatan Santri Putera terjun langsung ke lapangan untuk mengawasi setiap keberjalanan porogram di lapangan.

2. Metode Semi langsung

Metode semi langsung yang diterapkan dalam Manajemen Pendidikan Karakter Gotong Royong di Pesantren Ummul Quro al-Islami adalah dengan menggunakan mata-mata atau dikenal istilah jasus. Jasus atau mata-mata diambil dari santri yang melanggar disiplin pesantren. Santri yang melanggar disiplin pesantren tersebut diberikan hukuman oleh pengurus Ikatan Santri Putera untuk mencar santri yang melanggar disiplin.

3. Metode Tidak Langsung

Metode tidak langsung yang dilakukan Pesantren Ummul Quro al-Islami dalam Manajemen Pendidikan Karakter adalah dengan cara ketua Majelis Pembimbing Organisasi Santri menerima foto laporan dari grup telegram. Sedangkan pada Pengurus Ikatan Santri Putera dilakukan dengan cara Ketua Ikatan Santri Putera menerima laporan pelanggaran atau permasalahan dari anggota-anggotanya.

Informasi yang tepat dan akurat dapat diperoleh dapat diperoleh dalam kegiatan evaluasi (Wiyono dan Sunarni, 2009). Evaluasi pada dasarnya adalah kegiatan mengukur dan menilai suatu program untuk diadakan perbaikan dalam langkah selanjutnya.

Evaluasi yang dilaksanakan di Pesantren Ummul Quro al-Islami terbagi menjadi dua, yaitu evaluasi wajib yang dilaksanakan dua minggu sekali. Ada pun yang terlibat dalam evaluasi ini adalah Pengurus Majelis Pembimbing Organisasi 
dan Pengurus Ikatan Santri Putera. Sedangkan evaluasi kondisional yaitu evaluasi yang dilaksanakan satu minggu satu kali. Evaluasi ini dilaksanakan berdasarkan kesepakatan baik antar anggota bagian atau pun bagian Pengurus Bidang Ikatan Santri Putera dengan Pembimbing Bidang Majelis Pembimbing Organisasi, ada pun yang terlibat dalam evaluasi ini adalah pembimbing bidang Pengurus Ikatan Santri Putera dan Pengurus Bidang Majelis Pembimbing Organisasi.

\section{Faktor Pendukung dan Penghambat}

Pesantren Ummul Quro al-Islami dalam melaksanakan Manajemen Pendidikan Karakter Gotong Royong memiliki faktor pendukung dan penghambat. Faktor pendukung dan penghambat ini dipengaruhi oleh faktor internal dan faktor eksternal. Faktor internal adalah faktor yang berkaitan dengan Majelis Pembimbing Organisasi karena Majelis Pembimbing Organisasi sebagai sebuah representasi dari bagian Kesiswaan Pesantren Ummul Quro al-Islami. Sedangkan faktor eksternal adalah faktor yang kaitannya di luar dari Majelis Pembimbing Organisasi. Alasan peneliti menggunakan klasifikasi tersebut adalah karena Pesantren Ummul Quro al-Islami memiliki bagian tersendiri misalnya bagian pengelolaan pendidik di bawah bagian biro pendidikan.

Adapun Faktor Pendukung internal adalah sebagai berikut:

1. Mayoritas Pembimbing Organisasi adalah alumni Pesantren Ummul Quro al-Islami, hal ini menjadi faktor pendukung karena akan lebih mempermudah dalam menjaga tradisi-tradisi Pesantren;

2. Kesadaran Majelis Pembimbing Organisasi dalam menjalankan tugas dan kesadaran dalam mengabdi kepada Pesantren.

Ada pun faktor pendukung eksternalnya adalah sebagai berikut:

1. Adanya relasi dengan Pemerintah setempat dan tokoh-tokoh berpengaruh (Kaum Agamawan, intelektual, akademisi, dan penulis);

2. Sarana dan Prasarana yang memadai;

3. Adanya dukungan dari Pimpinan Pesantren baik moril atau pun materil.

Sedangkan faktor penghambat internal adalah adanya kecemburuan sosial antara asatidz yang tinggal di dalam komplek pesantren dan di luar komplek pesantren dalam pelimpahan tugas; Sedangkan Faktor Penghambat eksternal adalah: adanya double duties antara jam mengajar dan tugas menjadi MPO sehingga dapat mengganggu kinerja MPO.

Hasil yang dicapai dari Manajemen Pendidikan Karakter Gotong Royong di Pesantren Ummul Quro al-Islami tersusun dengan baik khususnya meliputi fungsi Manajemen Pelaksanaan Manajemen Pendidikan Karakter Gotong Royong dan Pengawasan Manajemen Pendidikan Karakter Gotong Royong di Pesantren Ummul Quro al-Islami. Akan tetapi, pada tahap Perencanaan Manajemen Pendidikan Karakter dan Pengorganisasian Manajemen Pendidikan Karakter Gotong Royong Perlu ditingkatkan terutama mengenai perumusan karakter gotong royong dan pembuatan Standar Operational Procedure tertulis. Meskipun tidak ada SOP, akan tetapi proses pelaksanaan Manajemen Pendidikan Karakter Gotong Royong berjalan dengan baik karena rasa pengabdian kepada pesantren menjadi motivasi internal dalam menjalankan fungsi Majelis Pembimbing Organisasi meskipun tidak ada SOP tertulis.

\section{SIMPULAN}


Manajemen Pendidikan Karakter Gotong Royong di Pesantren Ummul Quro al-Islami tersusun dengan baik khususnya meliputi fungsi Manajemen Pelaksanaan Manajemen Pendidikan Karakter Gotong Royong dan Pengawasan Manajemen Pendidikan Karakter Gotong Royong di Pesantren Ummul Quro alIslami. Akan tetapi, pada tahap Perencanaan Manajemen Pendidikan Karakter dan Pengorganisasian Manajemen Pendidikan Karakter Gotong Royong Perlu ditingkatkan terutama mengenai perumusan karakter gotong royong dan pembuatan Standar Operational Procedure tertulis. Meskipun tidak ada SOP, akan tetapi proses pelaksanaan Manajemen Pendidikan Karakter Gotong Royong berjalan dengan baik karena rasa pengabdian kepada pesantren menjadi motivasi internal dalam menjalankan fungsi Majelis Pembimbing Organisasi meskipun tidak ada SOP tertulis.

\section{REFERENSI}

Asmani, J. M. (2012). Buku Panduan Internalisasi Pendidikan Karakter di Sekolah. Diva Press.

Aziz, A. Wahab. (2011). Anatomi Organisasi dan Kepemimpinan Pendidikan.

Badrudin. (2013). Dasar-dasar Manajemen. Alfabeta.

Dhofier, Z. (2015). Tradisi Pesantren. LP3ES.

Koentjaraningrat. (2009). Pengantar IImu Antropologi. Rineka Cipta.

Mahmud. (2012). Sosiologi Pendidikan. Pustaka Setia.

Maisaro, A., Wiyono, B. B., \& Arifin, I. (2018). Manajemen Program Penguatan Pendidikan Karakter Di Sekolah Dasar. JAMP : Jurnal Administrasi Dan Manajemen Pendidikan, 1(3), 302-312. https://doi.org/10.17977/um027v1i32018p302

Marzali, A. (2009). Antropologi dan Pembangunan Indonesia. Kencana.

Muhaimin. (2010). Manajemen Pendidikan Aplikasinya Dalam Penyusunan Rencana Pengembangan Sekolah/Madrasah. Kencana Prenada Media Group.

Muhibbin Syah, Anang Solohin Wardan, Miftah Fauzi Rakhmat, \& Muchlis. (2017). Psikologi pendidikan: Dengan pendekatan baru (22nd ed.). Penerbit PT Remaja Rosdakarya.

Mulyasa. (2011). Manajemen Berbasis Sekolah, Konsep, Strategi dan Implementasi. PT Remaja Rosdakarya.

Mulyasa. (2012). Manajemen Pendidikan Karakter. PT Bumi Aksara.

Mulyasa. (2014). Pengembangan dan Implementasi Kurikulum 2013. PT Remaja Rosdakarya.

Rica, L. (2017). Manajemen Pendidikan Karakter AUD. 2(1), 16.

Rivai, V. (2009). Education management: Analisis teori dan praktik-Eprint UIN Raden Fatah Palembang. http://eprints.radenfatah.ac.id/420/

Robbins, S. P. (1996). Perilaku Organisasi (Edisi ke 7). Prehallindo.

Rusmaini, R. (2017). Manajemen Pendidikan Karakter di Lembaga Pendidikan Islam. El-Idare: Jurnal Manajemen Pendidikan Islam, 3(1), 132-147.

Samsirin, S. (2015). Konsep Manajemen Pengawasan dalam Pendidikan Islam. At-Ta'dib, 10(2), Article

2. https://ejournal.unida.gontor.ac.id/index.php/tadib/article/view/461

Sugiyono. (2013). Metode Penelitian Kuantitatif Kualitatif dan R\&D. Alfabeta. 